\title{
PENGARUH BANTUAN PAKET SEMBAKO DAN BANTUAN LANGSUNG TUNAI SELAMA PANDEMI COVID-19 TERHADAP KELANGSUNGAN HIDUP MASYARAKAT
}

\author{
Hendra Sukmana \\ Program Studi Administrasi Publik, Universitas Muhammadiyah Sidoarjo. \\ Korespondensi: hendra.sukmana@umsida.ac.id
}

\begin{abstract}
The purpose of the research, one of which is to prove the effect of food package assistance and also direct cash assistance on the survival of the community during the Covid-19 pandemic. The quantitative approach is carried out using a sample of 80 respondents with multiple linear regression analysis techniques. The data collection technique is done by using a questionnaire. The results of the study indicate that first, the basic food package assistance program has a significant contribution to the survival of people's lives. Second, the cash transfer program has a significant contribution to the survival of the community. Third, the basic food package assistance program and direct cash assistance have a significant contribution to the survival of people's lives. Based on the results of research and findings in the field, the following suggestions are obtained: first, the community needs more ongoing assistance, such as employment opportunities and useful equipment assistance. to improve skills and expertise for business actors. Second, a re-evaluation of the aid distribution process is carried out so that it can be felt by the community, such as being more fair and wise in the process of collecting data on aid beneficiaries. Third, an evaluation is needed in the data collection process, where this process must prioritize deliberation from the $R T$ to the village level, in order to obtain data that is in accordance with the value of propriety and the aspect of willingness. Based on this, the direct package assistance program and also direct cash assistance have a significant contribution to the survival of the community. Other results show that the cash transfer program has the most significant contribution in influencing the survival of the community.
\end{abstract}

Article Histori:

Accepted: $10 / 5 / 2021$

Review: 4/10/2021

Publish: 31/10/2021

Keyword: food package assistance,cash direct assistance,life sustainability.

\section{PENDAHULUAN}

Adanya wabah Covid-19 yang mengancam kesehatan, seperti yang di umumkan oleh World Health Organization (WHO) menjadi pandemi global yang penyebarannya relatif cepat dan menjadi topik serta permasalahn bagi beberapa negara. Indonesia termasuk yang memiliki jumlah kasus terinfeksi virus Covid-19 dimana setiap hari nya terus mengalami peningkatan. Hingga tanggal 19 April 2021 total kasus terinfeksi positif 1,6 juta, dimana 1,46 juta sembuh dan korban meninggal dunia 43.424 (Satgas Covid-19, 2021). Pemerintah selalu melakukan pembaharuan data Covid-19 untuk memantau perkembangan kasus dan juga sebagai bahan pengambilan kebijakan penanggulangan. Wabah pandemi Covid-19 berdampak pada hampir semua aspek kehidupan, tidak terkecuali aspek ekonomi. Hampir semua negara ikut merasakan dampak ekonomi dari adanya pandemi Covid-19. Sektor industri mengalami penurunan yang signifikan, dimana diikuti dengan menurunnya daya beli masyarakat, 
semakin membuat perekonomian menjadi lesu (Handayani, 2020).

Indonesia menjadi salah satu negara yang merasakan dampak negatif pada sektor dari Covid-19. Berdasarkan pernyataan Menteri Perkonomian, pertumbuhan ekonomi Indonesia tertekan pada level 2,5\% sampai 0\% (Liviana, et al., 2020). Untuk mengurangi dampak negatif tersebut, pemerintah Indonesia melakukan berbagai strategi dan kebijakan-kebijakan yang dapat memperkuat perlindungan sosial ekonomi masyarakat, seperti bantuan sembako, bantuan sosial tunai atau bantuan langsung tunai, listrik gratis, program kartu prakerja, subsidi gaji karyawan dan bantuan usaha mikro kecil. Beberapa program bantuan adalah program bantuan yang telah rutin dilaksanakan, namun denganadanya pandemi Covid-19, pemerintah meningkatkan jumlah penerima program bantuan tersebut.

Di Indonesia bantuan langsung tunai pertama kali dilakukan pada tahun 2005, yang berlanjut di tahun 2009, dimana pada tahun 2013 terjadi perubahan nama menjadi bantuan langsung sementara masyarakat (Stamboel, 2012). Program bantuan langsung tunai dilakukan pemerintah dengan tujuan untuk menjaga daya beli masyarakat serta dapat terbebas dari keterpurukan, sebagai akibat adanya pandemi Covid-19 (Nurahmawati dan Hartini, 2020). Pemerintah melalui Kementarian Sosial terus berusaha mengembangkan program bantuan untuk dapat mengurangi beban masyarakat, dengan meningkatkan jumlah penerima bantuan, program keluarga harapan atau $\mathrm{PKH}$, bantuan non tunai atau sembako dengan perluasan mencapai 44.742 kepala keluarga di Kabupaten Sidoarjo Jawa Timur.

Disisi lain, cepatnya penyebaran Covid-19 tidak sejalan dengan semakin cepatnya program pemerintah terealisasikan (Nurul, et al., 2020). Beberapa masyarakat berpendapat bahwa proses penyaluran bantuan baik dari pemerintah pusat maupun pemerintah daerah terkesan lambat diterima oleh masyarakat yang merasakan dampak pandemi (Utomo,Yuliyanti\& Widiyanto, 2021). Diketahui banyak faktor yang menyebabkan keterlambatan realisasi program, seperti jarak antara pemerintah pusat dengan masyarakat yang jauh, sistem regulasi penyaluran dari pintu ke pintu sehingga memakan waktu yang relatif lama, serta perspektif terhadap ketidak validan data penerima bantuan (Mufida, 2020).

Berdasarkan studi yang dilakukan selama proses penyaluran program bantuan sosial, ada beberapa tantangan yang dihadapi, diantaranya ketepatan pencairan dana sesuai dengan manfaat, penyaluran nilai serta besarnya bantuan yang tepat, dan durasi dari dilaksanakannya program bantuan (Pramanik, 2020). Pemerintah kian sigap dalam membantu masyarakat terdampak pandemi, melalui Kementerian Sosial pemerintah memberikan kuota 464 ribu penerima, tetapi masyarakat harus membuka atau membuat rekenang bank serta harus mengeluarkan biaya minimal 150 ribu rupiah untuk membuka rekening. Alternaif lain penyaluran dapat dilakukan melalui kantor Pos Indonesia, akan tetapi masyarakat yang memiliki tempat tinggal jauh dari perkotaan akan mengeluarkan biaya transportasi (Mufida, 2020). Guna mencapai efektivitas pelaksanaan penyaluran bantuan, pemerintah melalui Direktoral Jenderal Kependudukan dan Pencatatan Sipil yang bekerjasama dengan pemerintah daerah terkait terus bergerak memperbaiki ketepatan status penerimaan bantuan.

Tujuan utama diadakannya program bantuan langsung tunai oleh pemerintah, yaitu untuk meningkatkan kelangsungan hidup dan membangkitkan masyarakat dari keterpurukan ekonomi dimasa pandemi. Pelaksanaan program tersebut diharapkan dapat dirasakan oleh masyarakat, serta menyasar pada warga masyarakat yang terdampak langsung dan tidak langsung. 
Besarnya jumlah bantuan yang disalurkan pemrintah yaitu Rp 600.000 per bulan setiap kepala keluarga. Ada beberapa syarat yang ditetapkan pemerintah, untuk mendapatkan bantuan tunai, diantaranya (1) Calon penerima bantuan merupakan masyarakat yang terdaftar dalam pencatatan RT/RW dan juga desa. (2) Calon penerima bantuan merupakan masyarakat yang kehilangan pekerjaan atau mata pencaharian sebagai akibat pandemi. (3) Tidak terdaftar sebagai penerima bantuan sosial lain yang diselenggarakan oleh pemerintah pusat. Artinya calon penerima yang telah terdaftar mendapatkan bantuan langsung tunai dari dana desa tidak berhak atau tidak bisa mendaftar sebagai penerima program bantuan $\mathrm{PKH}$, paket sembako, kartu sembako, kartu prakerja dan bantuan pangan non tunai lainnya. (4) Calon penerima yang tidak terdaftar penerima bansos lain tetapi belum terdaftar oleh pihak RT/RW, bisa langsung mengubungi atau menginformasikan ke pihak desa. (5) Calon penerima yang tepat memenuhi syarat, tetapi belum mempunyai kartu penduduk dan nomor induk kependudukan bisa memperoleh bantuan langsung tunai, dengan syarat membuat kartu tanda penduduk terlebih dahulu.

Masyarakat menengah ke bawah menjadi golongan yang paling berdampak akibat adanya wabah pandemic (Livana, et al., 2021). Hal ini bisa disebabkan karena banyaknya industri atau perusahaan yang terpaksa merumahkan karyawannya bahkan harus melakukan pemutusan hubungan kerja. Sehingga, beban ekonomi keluarga akan semakin bertambah dengan tidak adanya pekerjaan. Masyarakat akan mengalami kesulitan dalam memenuhi kebutuhan hidup sehari-hari jika tidak mempunyai sumber pendapatan yang pasti. Usaha kecil juga mendapatkan dampak, seperti sulitnya mempertahankan usahanya. Jika tidak dapat menentukan strategi usaha yang tepat, bukan tidak mungkin mereka akan mengalami kebangkrutan bahkan kemiskinan (Suari dan Giri, 2021).

\section{KAJIAN LITERATUR Penelitian Terdahulu}

Nuniek (2020) dengan judul " Dampak Bantuan Paket Sembako dan Bantuan Langsung Tunai terhadap Kelangsungan Hidup Masyarakat di Kota Padalarang Pada Masa Pandemi Covid-19" menunjukkan bahwa bantuan yang diberikan oleh Pemerintah Kota Padalarang pada saat pandemi Covid-19 dirasa sangat tepat. Hal tersebut dikarenakan pandemi Covid-19 menyebabkan masyarakat Padalarang tidak bisa memperoleh penghasilan, sehingga kelangsungan hidup terancam. Oleh karena itu bantuan yang diberikan sangat membantu bagi kelangsungan hidup masyarakat Kota Padalarang di kala pandemi.

Fitria, dkk (2020) dengan judul "Efektivitas Penyaluran Bantuan Sosial Dari Pemerintah untuk Disalurkan Kepada Masyarakat Terdampak Pandemi Covid-19 di Kabupaten Ponorogo Tahun 2020" menunjukkan bahwa efektivitas terhadap bantuan sosial Tunai(BST) sudah cukup terrealisasikan dengan baik. Bantuan yang disalurkan sebanyak 9 tahap tersebut telah diterima oleh masyarakat yang berhak menerima, akan tetapi pada 3 tahap terakhir bantuan sosial tunai tersalurkan sebanyak 3 kali dalam waktu yang bersamaan. Namun terdapat permasalahan dari penyaluran bantuan Covid-19 ini yaitu kurangnya bahkan tidak adanya sosialisasi dari pemerintah Kabupaten Ponorogo terhadap bantuan tersebut sehingga banyak dari masyarakat yang belum memahami secara pasti tentang bantuan yang diberikan selama masa pandemi tersebut. Pada aspek ketepatan sasaran masih banyak masyarakat yang tumpang tindih terhadap data yang 
menjadi acuan untuk pemberian bantuan tersebut, sehingga efektivitas dari ketepatan sasaran banyak menimbulkan prokontra. Pada aspek tujuan program baik dari masyarakat maupun pihak pelaksana sudah menciptakan supaya keefektivan dari penyaluran bantuan sosial ini berjalan dengan lancar, namun pada kenyataanya hanya pihak pelaksana yang memahami tentang bantuan BST tersebut sedangkan masyarakat yang menerima tidak banyak yang paham tentang bantuan selama keadaan wabah Covid-19 tersebut. Faktor penghambat yang lain pasca dilakukan nya program bantuan sosial ini adalah validasi data yang kurang efektiv karena terdapat NIK yang berbeda pada saat pencairan dilakukan.

Fadilah (2021) dengan judul penelitian "Bantuan Sosial Sembako dan Bantuan Sosial Tunai" di Desa Mompang Julu Kecamatan Panyabunga Utara Kabupaten Mandailing Natal menjelaskan bahwa pelaksanaan Bantuan Sosial Sembako dan Bantuan Sosial Tunai (BST) dalam penanganan dampak Covid-19 belum berjalan dengan lancar dan baik. Hal tersebut diakibatkan kurang adanya transparansi dan terjadinya pemotongan dana.

Muga, dkk (2021) dengan judul penelitian" Dampak Penyaluran Bantuan Sosial Tunai Pandemi Covid-19 (Studi Kasus di Kelurahan Sikumana-Kota Kupang) menunjukkan bahwa pengelolaan bantuan Covid-19 dari kelurahan Sikumana kepada masyarakat belum optimal. Hal tersebut dikarenakan dalm hal pelaksanaan penyaluran masih belum dapat memberikan pemahaman yang baik kepada masyarakat terdampak tentang kemanfaatan bantuan tersebut. Selain itu kesadaran masyarakat mengenai pembaruan data juga sangat minim, sehingga masih terjadi pendobelan data di kelurahan.

Peraturan Menteri Keuangan Nomor 254/PMK.05/2015 menjelaskan pada hakikatnya bantuan sosial merupakan pemberian bantuan yang sifatnya tidak secara terus menerus dan selektif dalam bentuk uang/barang kepada masyarakat yang bertujuan untuk peningkatan kesejahteraan masyarakat. Dalam pemeberian bantuan sosial, baik Pemerintah Pusat dan Pemerintah Daerah sebagai pemberi bantuan sosial maupun Masyarakat/Lembaga Kemasyarakatan sebagai penerima bantuan sosial mempunya kewajiban untuk mempertanggungjawabkan bantuan sosial sesuai porsinya berdasarkan ketentuan yang berlaku.

Sedangkan untuk siapa saja penerima bantuan sosial, Pemerintah menetapkan sejumlah syarat bagi masyarakat yang ingin mendapatkan bantuan sosial tunai tersebut. Pertama, Calon penerima adalah masyarakat yang masuk dalam pendataan RT/RW dan berada di Desa; Kedua, Calon penerima adalah mereka yang kehilangan mata pencarian di tengah pandemi corona. Ketiga, Calon penerima tidak terdaftar sebagai penerima bantuan sosial (bansos) lain dari pemerintah pusat. Ini berarti calon penerima BLT dari Dana Desa tidak menerima Program Keluarga Harapan (PKH), Kartu Sembako, Paket Sembako, Bantuan Pangan Non Tunai (BPNT) hingga Kartu Prakerja. Keempat, jika calon penerima tidak mendapatkan bansos dari program lain, tetapi belum terdaftar oleh RT/RW, maka bisa langsung menginformasikan ke aparat desa. Kelima, Jika calon penerima memenuhi syarat, tetapi tidak memiliki Nomor Induk Kependudukan (NIK) dan Kartu Penduduk (KTP), tetap bisa mendapat bantuan tanpa harus membuat KTP lebih dulu. Tapi, penerima harus berdomisili di desa tersebut dan menulis alamat lengkapnya. Keenam, jika penerima sudah terdaftar dan valid maka BLT akan diberikan melalui tunai dan non tunai. Non tunai diberikan melalui transfer ke rekening bank penerima dan tunai boleh menghubungi aparat desa, bank milik negara atau diambil langsung di kantor pos terdekat (Bappenas, 2020).

\section{METODE PENELITIAN}

Penelitian dilakukan dengan pendekatan kuantitatif, dengan jeniskausal, adapun alat untuk pengumpulan data dilakukan dengan 
metode angket atau kuesioner. Penelitian kausal memiliki tujuan untuk mengetahui pengaruh yang terjalin antara satu atau lebih variabel bebas pada variabel terikat, dimana tujuan pada penelitian ini yaitu mengetahui dampak atau pengaruh pemberian bantuan paket

Tabel 1. PengukuranVariabel sembako dan bantuan langsung tunai selama pandemi terhadap kelangsungan kehidupan masyarakat di Kecamatan Tulangan Kabupaten Sidoarjo.

Pengukuran variabel dalam penelitian ini disajikan pada tabel sebagai berikut:

\begin{tabular}{|c|c|}
\hline Variabel & Pengukuran (Indikator) \\
\hline $\begin{array}{l}\text { Bantuan paket } \\
\text { sembako }\left(X_{1}\right)\end{array}$ & $\begin{array}{l}\text { a. Tersalurnya bantuan berupa paket sembako kepada masyarakat } \\
\text { kecamatan Tulangan Sidoarjo secara langsung dan benar. } \\
\text { b. Ketepatan status masyarakat penerima bantuan. } \\
\text { c. Penyaluran bantuan tepat sasaran. }\end{array}$ \\
\hline $\begin{array}{l}\text { Bantuan } \\
\text { langsung } \\
\text { tunai }\left(\mathrm{X}_{2}\right)\end{array}$ & $\begin{array}{l}\text { a. Tersalurkannya bantuan langsung tunai kepada masyarakat } \\
\text { kecamatan Tulangan Sidoarjo secara langsung dan benar. } \\
\text { b. Ketepatan status masyarakat penerima bantuan. } \\
\text { c. Penyaluran bantuan tetap sasaran. }\end{array}$ \\
\hline $\begin{array}{l}\text { Kelangsungan } \\
\text { kehidupan } \\
\text { masyarakat } \\
\text { (Y) }\end{array}$ & $\begin{array}{l}\text { a. Kehidupan masyarakat terbantu dengan adanya program bantuan } \\
\text { pemerintah. } \\
\text { b. Masyarakat terbantu memenuhi kebutuhan sehari-hari dengan } \\
\text { adanya program bantuan pemerintah. }\end{array}$ \\
\hline & $\begin{array}{l}\text { c. Program bantuan dapat membantu menggantikan pendapatan } \\
\text { masyarakat sebagai dampak dari pandemi. }\end{array}$ \\
\hline
\end{tabular}

Populasi yang digunakan adalah masyarakat kecamatan Tulangan Sidoarjo yang mendapatkan program bantuan paket sembako maupun bantuan langsung tunai. Dalam penelitian ini peneliti hanya mengambil sampel 80 responden, yaitu masyarakat yang bersedia menjadi sampel dan mengisi kuesioner. Adapun teknik analisis data yang dilakukan yaitu analisis regresi linier berganda, dengan pengujian hipotesis uji parsial dan uji simultan dengan program analisis data SPSS.

\section{HASIL DAN PEMBAHASAN}

Berikut ini akan disajikan hasil uji validitas yang dipaparkan melalui tabel berikut ini

Tabel 2. Hasil Uji Validitas

\begin{tabular}{cccc}
\hline Variabel & Indikator & $r$ hitung & rkritis \\
\hline & $\mathrm{X}_{1 \cdot 1}$ & 0,643 & \\
Bantuan Paket Sembako $\left(\mathrm{X}_{1}\right)$ & $\mathrm{X}_{1 \cdot 2}$ & 0,742 & \\
& $\mathrm{X}_{1 \cdot 3}$ & 0,583 & \\
& $\mathrm{X}_{1 \cdot 4}$ & 0,746 & \\
& $\mathrm{X}_{1 \cdot 5}$ & 0,711 & \\
& $\mathrm{X}_{1 \cdot 6}$ & 0,720 & \\
& $\mathrm{X}_{2 \cdot 1}$ & 0,590 & \\
Bantuan Langsung Tunai $\left(\mathrm{X}_{2}\right)$ & $\mathrm{X}_{2 \cdot 2}$ & 0,516 & \\
& $\mathrm{X}_{2 \cdot 3}$ & 0,649 & \\
& $\mathrm{X}_{2 \cdot 4}$ & 0,585 & \\
Kelangsungan Kehidupan & $\mathrm{X}_{2 \cdot 5}$ & 0,598 & \\
Masyarakat $(\mathrm{Y})$ & $\mathrm{X}_{2 \cdot 6}$ & 0,597 &
\end{tabular}




\begin{tabular}{cccc}
\hline Variabel & Indikator & $r$ hitung & $r$ kritis \\
\hline & $\mathrm{Y}_{1.3}$ & 0,720 & \\
& $\mathrm{Y}_{1.4}$ & 0,647 & \\
$\mathrm{Y}_{1.5}$ & 0,546 & \\
& $\mathrm{Y}_{1.6}$ & 0,341 & \\
\hline
\end{tabular}

Berdasarkan tabel 2, diketahui untuk bahwa butir pernyataan sudah valid dan masing-masing item pernyataan memperoleh bisa digunakan untuk pengujian nilai rhitung lebih dari 0,3. Hal ini menunjukkan selanjutnya.

Tabel 3. Hasil Uji Reliabilitas

\begin{tabular}{lcc}
\hline \multicolumn{1}{c}{ Variabel } & Cornbach's Alph $a$ & Keterangan \\
\hline Bantuan Paket Sembako $\left(\mathrm{X}_{1}\right)$ & 0,880 & Reliabel \\
Bantuan Langsung Tunai $\left(\mathrm{X}_{2}\right)$ & 0,822 & Reliabel \\
Kelangsungan Kehidupan & 0,825 & Reliabel \\
Masyarakat $(\mathrm{Y})$ & \\
\hline
\end{tabular}

Berdasarkan tabel 3, hasil pengujian reliabilitas instrument menunjukkan bahwa masing-masing variabel memiliki nilai alpha cronbach lebih besar dari 0,6. Artinya

Tabel 4. Hasil Uji Asumsi Klasik

\begin{tabular}{|c|c|c|c|c|}
\hline Uji Asumsi & \multicolumn{2}{|l|}{ Hasil } & Kriteria & Keterangan \\
\hline Uji Normalitas & \multicolumn{2}{|l|}{0,194} & Sig. $>0,05$ & $\begin{array}{l}\text { Data terdistribusi } \\
\text { normal }\end{array}$ \\
\hline \multicolumn{5}{|l|}{ Uji Linieritas } \\
\hline $\mathrm{X}_{1}$ & Sig. $=0,496$ & & Sig. $>0,05$ & Terdapat hubungan \\
\hline $\mathrm{X}_{2}$ & Sig. $=0,248$ & & & $\begin{array}{l}\text { linier } \\
\text { Terdapat hubungan } \\
\text { linier }\end{array}$ \\
\hline Uji Multikolinieritas & Tolerance & VIF & & \\
\hline $\mathrm{X}_{1}$ & $0,9591,043$ & & Tolerance $>0,1$ & Bebas multikolinieritas \\
\hline $\mathrm{X}_{2}$ & $0,9591,043$ & & VIF $\quad<10$ & Bebas multikolinieritas \\
\hline \multicolumn{5}{|l|}{ Uji Heteroskedatisitas } \\
\hline $\mathrm{X}_{1}$ & Sig. $=0,083$ & & Sig. $>0,05$ & Bebas \\
\hline $\mathrm{X}_{2}$ & Sig. $=0,263$ & & & $\begin{array}{l}\text { heteroskedastisitas } \\
\text { Bebas }\end{array}$ \\
\hline Uji Autokorelasi & $\mathrm{DW}=2,018$ & & $\begin{array}{c}1,702<\mathrm{DW}< \\
2,298\end{array}$ & $\begin{array}{l}\text { heteroskedastisitas } \\
\text { Bebas autokorelasi }\end{array}$ \\
\hline
\end{tabular}

Tabel 5. AnalisisRegresi Linier Berganda

\begin{tabular}{llr}
\hline \multicolumn{2}{l}{ Model } & B \\
\hline 1 & (Constant) & 6.598 \\
\cline { 2 - 2 }$X_{1}$ & .106 \\
\hline$X_{2}$ & .630 \\
\hline
\end{tabular}

Berdasarkan tabel di atas, dapat dibuat persamaan regresi sebagai berikut:

$$
Y=6,598+0,106 X 1+0,630 X 2+e
$$

kesluruhan variabel memiliki penyataan yang handal atau reliabel, sehingga dapat digunakan untuk pengujian selanjutnya. 
koefisien tersebut menunjukkan bahwa dengan adanya kenaikan satu satuan variabel program bantuan paket sembako, memiliki kontribusi pada kenaikan variabel kelangsungan kehidupan masyarakat sebesar 0,106 satuan.

3. Variabel program bantuan langsung tunai (X2) memperoleh nilai koefisien positif sebesar 0,630. Nilai koefisien tersebut menunjukkan bahwa dengan adanya kenaikan satu satuanvariabel program bantuan langsung tunai, memiliki kontribusi pada kenaikan variabel kelangsungan kehidupan masyarakat sebesar 0,630 satuan.

Tabel 6. Hasil Uji KoefisienDeterminasi

\begin{tabular}{ccc}
\hline Model Regresi & $\mathrm{R}$ & R Square \\
\cline { 2 - 3 } & 0,831 & 0,690 \\
\hline
\end{tabular}

Berdasarkan tabel 6, diketahui nilai R2 sebesar 0,690 atau 79\%. Artinya naik turunnya variabel kelangsungan kehidupan masyarakat dapat dijelaskan oleh variabel program bantuan paket sembako dan program bantuan langsung tunai selama pandemi Covid-19.

Tabel 7. Hasil Uji Parsial (Uji t) dan Uji Simultan (F)

\begin{tabular}{lrrrr}
\hline \multicolumn{1}{c}{ Variabel } & \multicolumn{1}{c}{ thitung } & Signifikansi & \multicolumn{1}{c}{ F $_{\text {hitung }}$} & Signifikansi \\
\hline Bantuan Paket Sembako $\left(\mathrm{X}_{1}\right)$ & 2,645 & 0,010 & 85,753 & 0,000 \\
Bantuan Langsung Tunai $\left(\mathrm{X}_{2}\right)$ & 13,096 & 0,000 & & \\
\hline
\end{tabular}

berikut:

Tabel 7 dapat dijelaskan sebagai

1. Variebal bantuan paket sembako (X1) memperoleh nilai signifikansi sebesar 0,010, dimana nilai tersebut lebih kecil dari 0,05. Hal ini menunjukkan H1 diterima, yaitu bantuan paket sembako memiliki pengaruh signifikan terhadap kelangsungan kehidupan masyarakat ditengah pandemi Covid-19.

2 Variabel bantuan langsung tunai $(X 2)$ memperoleh nilai signifikansi sebesar 0,000, dimana nilai tersebut lebih kecil dari 0,05. Hal ini menunjukkan $\mathrm{H} 2$ diterima, yaitu bantuan langsung tunai memiliki pengaruh signifikan terhadap kelangsungan kehidupan masyarakat ditengan pandemi Covid-19.

Berdasarkan tabel 7 di atas, diperoleh nilai signifikansi sebesar 0,00, dimana nilai tersebut lebih kecil dari 0,05. Artinya secara simultan variabel bantuan paket sembako (X1) dan bantuan langsung tunai (X2) memiliki kontribusi signifikan terhadap kelangsung kehidupan masyarakat dimasa pandemi Covid-19, atau H3 diterima.

Pengaruh Program Bantuan Paket Sembako Terhadap Kelangsungan Kehidupan Masyarakat di Kecamatan Tulangan Sidoarjo

Berdasarkan hasil pengujian hipotesis, diketahui bahwa program bantuan paket sembako memiliki kontribusi signifikan terhadap kelangsungan hidup masyarakat di Kecamatan Tulangan Sidoarjo, dimana dengan bantuan sembako yang diterimanya dapat membantu meningkatkan kelangsungan kehidupan masyarakat. Adanya program bantuan pemerintah ditengah wabah pandemi, dianggap sebagai angin segar bagi masyarakat terutama kalangan menengah ke bawah, karena dengan program bantuan paket sembako dapat membantu masyarakat untuk memenuhi kebutuhan sehari-harinya. Program paket sembako yang diterima masyarakat berupa beras $5 \mathrm{~kg}$, gula pasir $2 \mathrm{~kg}$, mie instan, minyak makan 2liter dan sarden kaleng sebanyak 4 buah. Meskipun tidak sepenuhnya dapat mencukupi kebutuhan masyarakat, akan tetapi masyarakat sangat terbantu. Banyaknya warga masyarakat yang mengalami kehilangan mata pencarian akibat tempat kerja yang mengalami kerugian, menjadikan kualitas kehidupan masyarakat menurun. Adanya program bantuan sembako, mampu membantu masyarakat dalam meringankan beban biaya untuk memenuhi kebutuhannya (Citra, Muzalifahd an Ibrahim, 2021). 
Program bantuan berupa paket sembako memiliki tujuan untuk meringankan beban ekonomi masyarakat terdampak pandemi dan untuk memulihkan perekonomian masyarakat (Khoiriyah,et al.,2020). Berdasarkan keterangan masyarakat penerima manfaat bantuan sembako, mereka bisa menghemat pengeluaran rumah tangga karena sudah mendapatkan bantuan bahan makanan. Masyarakat dapat mengalokasikan uang yang dimiliki untuk memenuhi kebutuhan lainnya. Meskipun tidak sepenuhnya dapat mencukupi, masyarakat merasa terbantu dalam menjaga kelangsungan kehidupan (Nasrah, et al., 2020).

Kebutuhan untuk makanan seharihari masyarakat terbantu dengan adanya bantuan paket sembako (Pramisita dan Utama, 2020). Meskipun dari beberapa keterangan masyarakat penyaluran bantuan dinilai tertalu lama dan masih dijumpai beberapa ketidak akuratan data penerima manfaat. Adanya wabah pandemi, sangat terasa dampaknya bagi masyarakat kelangan menengah ke bawah, selain harus kehilangan pekerjaan, masyarakat juga dikeluhkan dengan semakin banyaknya kebutuhan terutama untuk menerapkan protokol kesehatan, seperti untuk membeli masker, hand sanitizer dan peralatan kesehatan lainnya (Khoriyah, et al., 2020).

\section{Pengaruh Program Bantuan Langsung Tunai Terhadap Kelangsungan Kehidupan Masyarakat di KecamatanTulangan Sidarjo}

Berdasarkan hasil pengujian hipotesis, diketahui bahwa bantuan langsung tunai memiliki kontribusi signifikan terhadap kelangsungan kehidupan masyarakat di Kecamatan Tulangan Kabupaten Sidoarjo. Artinya adanya bantuan langsung tunai yang diberikan pemerintah selama pandemi Covid-19, dapat meningkatkan kelangsungan kehidupan masyarakat. Bantuan berupa uang tunai dapat dimanfaatkan masyarakat penerima, untuk memenuhi kebutuhan sehari-hari, seperti untuk membeli kebutuhan konsumsi maupun untuk membeli kebutuhan kesehatan seperti masker. Masyarakat merasa terbantu dengan terselenggaranya bantuan langsung tunai, mengingat selama masa pandemi banyak masyarakat yang mengalami kehilangan mata pencaharian.

Tujuan utama pemberian bantuan langsung tunai dimasa pandemi, yaitu untuk mempertahankan daya beli masyarakat dan juga pelaku usaha untuk mempertahankan kelangsungan usaha (Riyanta, Nurcahyo, \& Santoso, 2020). Penyaluran progam bantuan langsung tunai dilaksanakan selama 3 bulan, dengan besar bantuan Rp 600.000 setiap bulannya. Pemberian bantuan ini secara umum sangat membantu meringankan beban ekonomi rumah tangga, dimana dimasa pandemi masyarakat dianjurkan beraktivitas dari rumah dan mengurangi interaksi ditempat umum. Dari sisi ekonomi, daya beli dan kelangsungan kehidupan masyarakat mengalami peningkatan, dengan terealisasinya progam bantuan langsung tunai (Iping, 2020).

Pandemi membawa dampak bagi seluruh kehidupan masyarakat, baik dari ekonomi maupun sosial (Maun, 2020). Tidak sedikit masyarakat harus kehilangan mata pencaharian sehingga sulit untuk memenuhi kebutuhan sehari. Bantuan langsung tunai membantu kelangsungan kehidupan masyarakat dari segi ekonomi, dimana bantuan ini tidak memperparah kondisi masyarakat miskin menjadi lebih miskin (Sumarto, 2018). Bantuan langsung tunai dapat menambah pendapatan masyarakat guna memenuhi kebutuhan, tetapi masih memiliki peranan yang relatif kecil. Hal ini dapat disebabkan karena jumlah bantuan yang diterima tidak berjumlah besar dan masih bersifat sementara (Wodiling, 2020). 
Pengaruh Program Bantuan Paket Sembako dan Program Bantuan Langsung Tunai Terhadap Kelangsungan Kehidupan Masyarakat di Kecamatan Tulangan Sidarjo

Berdasarkan hasil pengujian hipotesis, diketahui bahwa pemberian bantuan paket sembako dan bantuan langsung tunai memiliki kontribusi yang signifikan terhadap kelangsungan kehidupan masyarakat di Kecamatan Tulangan Sidoarjo. Meskipun tidak sepenuhnya dapat menutupi kebutuhan masyarakat, dengan adanya program bantuan pemerintanya itu bantuan berupa paket sembako dan bantuan langsung tunai sedikit mengurangi beban ekonomi masyarakat. Bantuan berupa paket sembako dapat dimanfaatkan masyarakat langsung untuk memenuhi kebutuhan konsumsi seharihari, sedangkan bantuan tunai dapat dimanfaatkan untuk menopang kebutuhan masyarakat, seperti untuk membeli keperluan dapur, keperluan kesehatan maupun keperluan lainnya.

Masyarakat yang menerima manfaat dari program bantuan pemerintah merasakan adanya perubahan dari segi ekonomi. Akan tetapi, masyarakat juga masih mengeluhkan sifat bantuan yang sementara (Wowiling, 2020). Tidak sedikit dari masyarakat yang menilai bantuan tidak begitu efektif, dimana masyarakat lebih membutuhkan bantuan yang dapat dimanfaatkan untuk jangka panjang, seperti bantuan lapangan pekerjaan, bantua nperalatan yang dapat meningkatkan keahlian serta keterampilan masyarakat dalam berusaha.

\section{PENUTUP}

Berdasarkan hasil analisis data dan pembahasan pada bab sebelumnya, dapat ditarik kesimpulan sebagai berikut: pertama, Program bantuan paket sembako memiliki kontribusi signifikan terhadap kelangsungan kehidupan masyarakat. Kedua, Program bantuan langsung tunai memiliki kontribusi signifikan terhadap kelangsungan kehidupan masyarakat. Ketiga, Program bantuan paket sembako dan bantuan langsung tunai memiliki kontribusi signifikan terhadap kelangsungan kehidupan masyarakat. Berdasarkan hasil penelitian dan temuan dilapangan, maka diperoleh saran sebagai berikut: pertama, Meskipun secara umum program bantuan sosial memiliki pengaruh terhadap kelangsungan kehidupan masyarakat dari segi ekonomi, masyarakat lebih membutuhkan bantuan yang sifatnya berlanjutan, seperti adanya lapangan pekerjaan maupun bantuan peralatan yang berguna untuk meningkatkan keterampilan dan keahlian bagi pelaku usaha. Kedua, Adanya dampak sosial yang timbul dari pelaksanaan penyaluran bantuan dibeberapa tempat. Disarakan pemerintah untuk melakukan evaluasi kembali proses penyaluran bantuan agar dapat dirasakan manfaatkan bagi masyarakat, seperti dengan lebih adil dan bijak dalam proses pendataan penerima manfaat bantuan. Ketiga, Diperlukan evaluasi dalam proses pendataan, dimana proses ini harus lebih mengutamakan musyawarah dari tingkat RT sampai dengan desa, guna memperoleh data yang sesuai dengan nilai kepatutan dan aspek kerelaan.

\section{DAFTAR PUSTAKA}

Badan Perencanaan Pembangunan Nasional (BAPPENAS). 2020. Buku Saku Panduan Pendataan Bantuan Langsung Tunai - Dana Desa (BLT-DD, Juni 2020) . KOMPAK: Kolaborasi Masyarakat dan Pelayanan untuk Kesejahteraan Kemitraan Pemerintah Australia - Indonesia

Citra, S. F., Muzalifah, T., \& Ibrahim, L. (2021). Analisis Kesesuaian Penerima dan Penggunaan Dana Bantuan Sosial Pandemi Covid-19 pada Masyarakat Gampong Sapik dan Gampong Air Berudang, Aceh Selatan. Jurnal Riset dan Pengabdian Masyarakat, Volume 1 Nomor 1, 12-23.

P-JIAP: Vol. 6 (2) 2021

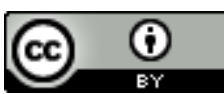


Fadilah, R., Siregar, F.A., \& Harahap, I. (2021). Bantuan Sosial Sembako dan Bantuan Sosial Tunai. Jurnal ElThawalib, Vol. 2 No.3, 167-179.

Fitria, F. N., Wijaya, S. R., \& Abhipraya, F.A. (2020). Efektivitas Penyaluran Bantuan Sosial Dari Pemerintah Untuk Disalurkan Kepada Masyarakat Terdampak Pandemi Covid-19 Dikabupaten Ponorogo Tahun 2020. Jurnal Politikom Indonesiana: Kajian Ilmu Pemerintahan, Ilmu Politik dan Ilmu Komunikasi, Vol.6, No. 1, 40-50.

Handayani, S. (2020). Bantuan Sosial bagi

Warga Lanjut Usia di Masa Pandemi. Journal of Social Development Studies, Volume 1 Nomor 2, 61-75.

Iping, B. (2020). Perlindungan Sosial Melalui Kebijakan Program Bantuan Langsung Tunai (Blt) Di Era Pandemi Covid-19: Tinjauan Perspektif Ekonomi Dan Sosial. JMPIS (Jurnal Manajemen Pendidikan dan Ilmu Sosial), Volume 1 Nomor 2, 516-526.

Khoiriyah, F., Oktavia, L., Zakiyah, N., \& Huda, M. A. (2020). The Effectiveness Of The Implementation Of Social Assistance On Communities Affected By Covid-19 In The Village Of Gedongarum Kanor District Bojonegoro District. Spirit Publik, Volume 15 Nomor 2, 97-110.

Livana, Suwoso, R. H., Febrianto, T., Kushindarto, D., \& Aziz, F. (2021). Dampak Pandemi Covid-19 Bagi Perekonomian Masyarakat Desa. Indonesian Journal of Nursing and Health Sciences, Volume 1 Nomor 1, 37-48.

Maun, C. E. (2020). Efektivitas Bantuan Langsung Tunai Dana Desa Bagi Masyarakat Miskin Terkena Dampak Covid-19 Di Desa Talaitad Kecamatan Suluun Tareran Kabupaten Minahasa Selatan. Jurnal Politico, Volume 9 Nomor 2, 1-16.
Mufida, A. (2020). Polemik Pemberian Bantuan Sosial. ADALAH : Buletin Hukum \& Keadilan, Volume 4 Nomor 1, 159-166.

Handayani, S. (2020). Bantuan Sosial bagi Warga Lanjut Usia di Masa Pandemi. Journal of Social Development Studies, Volume 1 Nomor 2, 61-75.

Iping, B. (2020). Perlindungan Sosial Melalui

Kebijakan Program Bantuan Langsung Tunai (Blt) Di Era Pandemi Covid-19: Tinjauan Perspektif Ekonomi Dan Sosial. JMPIS (Jurnal Manajemen Pendidikan dan Ilmu Sosial), Volume 1 Nomor 2, 516-526.

Khoiriyah, F., Oktavia, L., Zakiyah, N., \& Huda, M. A. (2020). The Effectiveness Of The Implementation Of Social Assistance On Communities Affected By Covid-19 In The Village Of Gedongarum Kanor District Bojonegoro District. Spirit Publik, Volume 15 Nomor 2, 97-110.

Livana, Suwoso, R. H., Febrianto, T., Kushindarto, D., \& Aziz, F. (2021). Dampak Pandemi Covid-19 Bagi Perekonomian Masyarakat Desa. Indonesian Journal of Nursing and Health Sciences, Volume 1 Nomor 1, 37-48.

Maun, C. E. (2020). Efektivitas Bantuan Langsung Tunai Dana Desa Bagi Masyarakat Miskin Terkena Dampak Covid-19 Di Desa Talaitad Kecamatan Suluun Tareran Kabupaten Minahasa Selatan. Jurnal Politico, Volume 9 Nomor 2, 1-16.

Muga, M.P., Kiak, N.T., \& Maak, C. S. (2021). Dampak Penyaluran Bantuan Sosial Tunai Pandemi Covid-19 (Studi Kasus di Kelurahan Sikumana - Kota Kupang). OECONOMICUS: Journal of Economics, Vol. 5, No. 2, 106-112.

Mufida, A. (2020). Polemik Pemberian Bantuan Sosial. ADALAH : Buletin 
Hukum \& Keadilan, Volume 4 Nomor 1, 159-166.

Nasrah, H., Irdayanti, Nesneri, Y., \& Hidayati, F. (2020). Implementasi Program Jaring Pengaman Sosial Pada Masa Pandemi Covid-19 Di Pekanbaru. Jurnal El-Riyasah, Volume 11 Nomor 2, 119-138.

Nurahmawati, F., \& Hartini, S. (2021). Implementasi Kebijakan Program Bantuan Langsung Tunai (BLT) Terhadap Warga Terdampak Covid-19 Di Desa Cibadak. JURMA : Jurnal Program Mahasiswa Kreatif, Volume 4 Nomor 2 , 160-165.

Nurul, H. P., Nikenindya, A. S., Wulandani, D. M., Putri, P. A., Putri, C. R., Qanita, Z., et al. (2020). Pembagian Paket Sembako Sebagai Bentuk Bantuan Sosial Kepada Pekerja Jalanan Di Wilayah Kelurahan Cilendek Timur Dalam Masa Transisi Pandemik Covid-19. Jurnal Layanan Masyarakat (Journal of Public Service), Volume 4 Nomor 2, 486-491.

Pramanik, N. D. (2021). Dampak Bantuan Paket Sembako Dan Bantuan Langsung Tunai Terhadap Kelangsungan Hidup Masyarakat Padalarang Pada Masa Pandemi Covid 19. INTELEKTIVA : JURNAL EKONOMI, SOSIAL \& HUMANIORA, Volume 1 Nomor 12, 113-120.

Pramisita, A. A., \& Utama, M. S. (2020). Efektivitas Dan Pengaruh Bansos Terhadap Tingkat Pemenuhan Kebutuhan Dasar Penduduk Lansia Kecamatan Mengwi Kabupaten
Badung. E-Jurnal EP Unud, Volume 9 Nomor 4, 780 - 809.

Riyanta, A. B., Nurcahyo, H., \& Santoso, J. (2020). Implementasi Paket Bantuan Sosial Sebagai Upaya Menghadapi Pandemi Covid-19. Jurnal Pengabdian UNDIKMA: Jurnal Hasil Pengabdian \& Pemberdayaan kepada Masyarakat, Volume 1 Nomor 2, 82-86.

Satgas Covid-19. Data Jumlah Terkonfirmasi Covid-2019.

Stamboel, K. A. (2012). Panggilan Keberpihakan : Strategi Mengakhiri Kemiskinan di Indonesia. Jakarta: PT. Gramedia Pustaka Utama.

Suari, N. M., \& Giri, N. P. (2021). Analisis Terhadap Potensi Maladministrasi Bantuan Langsung Tunai (BLT) Dana Desa Selama Pandemi Covid-19. Jurnal Kertha Negara, Volume 9 Nomor 2, 107-119.

Sumarto, M. (2018). Perlindungan Sosial dan Klientelisme Maka Politik Bantuan Tunai dalam Pemilihan Umum. Yogyakarta: Gadjah Mada University Press.

Utomo, A. D., Yuliyanti, T., \& Widiyanto, K. (2021). Peran Serta Program Bantuan Sosial Tunai Pemerintah Untuk Perbaikan Ekonomi Di Kecamatan Sumobito Kabupaten Jombang. Jurnal Dinamika Sosial, Volume 4 Nomor 1, 1-9.

Wowiling, R. (2021). Peran Pemerintah Desa Dalam Penyaluran Bantuan Langsung Tunai Pada Masyarakat Di Masa Pandemi Covid - 19 Di Kecamatan Maesaan Kabupaten Minahasa Selatan. Jurnal Politico, Volume 10 Nomor 4, 1-12. 